\title{
PARASITOLOGICAL AND MOLECULAR DETECTION OF THEILERIA EQUI IN DONKEYS IN ASSIUT GOVERNORATE
}

\author{
HUDA M. KURAA and BASEM R. NAGEIB
}

Parasitology department in Animal Health Research Institute, Assiut governorate, Egypt

Email: Huda5380@yahoo.com; Basem79eg@yahoo.com

(Manuscript received 8 January 2017 )

\begin{abstract}
$T$ heileria equi is a tick-borne hemoprotozoan parasite and one of the causative agents of equine piroplasmosis. Data on $T$. equi infection in donkeys are scarce in Assiut governorate, Egypt. This study was conducted on the prevalence of $T$. equi infection in donkeys by using micropscopic examination and polymerase chain reaction (PCR) assay. Out of 50 donkeys, blood samples examined for $T$. equi, $14 \%(7 / 50)$ were positive by microscopic examination and 38\% (19/50) by PCR. Prevalence of $T$. equi had high significant differences between microscopic examination and PCR assay. Prevalence of $T$. equi in male donkeys was $13.6 \%$ (3/22) by microscopic examination and $36.4 \%(8 / 22)$ by PCR. In female donkeys it was $14.3 \%(4 / 28)$ by microscopic examination and $39.3 \%(11 / 28)$ by PCR. No significant difference between the prevalence rate of infection in males and females were recorded. Microscopic examination of donkeys' blood smears stained with Giemsa stain revealed forms of theilerial schizogony in lymphocytes (Koch's blue bodies) and intra-erythrocytic relatively small, less than $2 \mu \mathrm{m}$ long pear-shaped and ring shaped merozoites of $T$. equi. The B1 gene specified for $T$. equi was detected by PCR in 19 blood samples. All positive samples with microscopic examination were also positive with PCR. The sensitivity, specificity and accuracy of PCR with respect to blood film examination were $61.3 \%, 100 \%$ and $82 \%$, respectively. So, PCR was found to be more sensitive, specific and accurate than blood film examination. The present results suggest that $T$. equi parasite is widely spread in Assiut governorate due to high exposure to ticks.

Keywords: Theileria equi - microscopic examination - PCR - Assiut governorate
\end{abstract}

\section{INTRODUCTION}

Principally, donkeys still considered as important animals in farms and have been trained and used in farming and transportation in many countries. Since donkeys are frequently kept outdoors, they are exposed to a high risk of tick bites and consequently to infection with blood parasites. Babesia caballi and $T$. equi have been already recognized as a serious problem of major economic importance in donkey husbandry, since the affected animals display loss of appetite and decreased working capacity (Machado et al., 2012). 
Mehlhorn and Schein (1998) redescribed the horse-parasitizing species Babesia equi as Theileria equi and thus transferred from one valid genus to another. It was reclassified as Theileria species because of the transstadial transmission in the vector and because sporozoites do not infect red blood cells but penetrate lymphocytes (or macrophages) where they develop into schizonts. The merozoites are released from the schizonts then enter the red blood cells where they grow into piroplasms (Schein et al., 1981). Further support for the close relation of $T$. equi with Theileria spp. also comes from the homology found between 30 and $34 \mathrm{kDa} T$. equi surface proteins and similar sized proteins of various Theileria spp. (Knowles et al., 1997). Genetically, this species had been proved to be more related to the genus Theileria than Babesia (Allsopp et al., 1994).

Equine theileriosis caused by $T$. equi considered to be the most pathogenic tickborne piroplasm of horses and was clinically characterized by fever of up to $40{ }^{\circ} \mathrm{C}$, anemia, depression, anorexia, icterus, enlarged lymph nodes, hepatomegaly, splenomegaly, hemoglobinuria, bilirubinuria, edema of distal limbs, pulmonary edema, nasal discharge, colic and petechial hemorrhages of the mucous membranes (Salib et al., 2013 and Sumbria et al., 2015).

Erythrocytic stages of $T$. equi were small in size (less than $2 \mu \mathrm{m}$ ) and were spherical, ovoid or cross shaped. They may be found either single, in pairs or in tetrads (Schein, 1988). Transplacental transmission of $T$. equi from carrier mares to asymptomatic foals can occur which becomes a serious economic problem for horse farmers (Allsopp et al., 2007).

Diagnosis of equine piroplasmosis can be performed by direct diagnosis includes demonstration of intraerythrocytic forms in Giemsa stained blood smears or by molecular techniques (OIE, 2014). Detection of parasite DNA by PCR has been known as a powerful tool both in the early phase of infection and in carrier animals (Rampersad et al., 2003).

Conventional techniques are the gold standard method to detect piroplasms in infected equids with acute signs (Böse et al., 1995). Although this method is simple, it is not very sensitive in cases of low parasitemia and does not permit diagnosis of mixed infections (Krause, 2003). So, molecular techniques have been developed in recent years for the detection of $T$. equi. These methods are based on species-specific PCR assays (Adaszek et al., 2011). The PCR method has been described as a molecular technique for sensitive, specific and reliable genomic detection of Babesia and Theileria parasites (Alhassan et al., 2005 and Davitkov et al., 2015). Diagnosis by PCR is sensitive enough to detect parasite DNA from $2.5 \mu \mathrm{l}$ blood sample with parasitemia of $0.000001 \%$ (Alhassan et al., 2007 and Sumbria et al., 2016). 
In Egypt, the data available on $T$. equi in donkeys is scarce and it is restricted to only few areas and to small numbers of samples. More studies using sensitive and specific diagnostic techniques are still required (Mahmoud et al., 2015). So, this study aimed to determine the prevalence of $T$. equi in donkeys in Assiut governorate by microscopic examination and PCR.

\section{MATERIALS AND METHODS}

Sampling: A total number of 50 blood samples were collected randomly from apparently healthy 50 donkeys in Assiut governorate. Blood samples were obtained from jugular vein of each donkey. The sex was recorded for each animal. The blood samples were collected in vacutainer tubes containing EDTA anticoagulant. Blood smears prepared and stained with Giemsa stain. The blood samples in vacutainer tubes stored at $-20^{\circ} \mathrm{C}$ until used for molecular analysis (PCR) (Sgorbini et al., 2015).

Microscopic examination: The prepared blood films were dried and fixed with absolute methyl alcohol for 7-10 min. These blood smears were stained with Giemsa stain according to Coles (1986) and examined with light microscope for the presence of haemoprotozoan parasite ( $T$. equi).

\section{Polymerase Chain Reaction (PCR)}

1. DNA extraction (Kim et al., 2008): Accurately $100 \mu \mathrm{l}$ of blood samples were diluted in the same volume of phosphate-buffered saline (PBS). DNA was extracted following the manufacturer's instructions of a commercial DNA blood Mini Kit (Qiagen, Valencia, CA, USA). All DNA extracts were stored at $-20{ }^{\circ} \mathrm{C}$ until used. This product was used as a template for PCR.

Primer sequences of $\boldsymbol{T}$. equi used for PCR identification system: Application of PCR for identification of B1 gene specified for $T$. equi was performed essentially by using primers (Biosearch Technologies, Inc., USA) as shown in the following table:

\begin{tabular}{|c|c|c|c|}
\hline \multicolumn{1}{|c|}{ Primer } & Oligonucleotide sequence $\left(5^{\prime} \rightarrow 3^{\prime}\right)$ & Productsize (bp) & Reference \\
\hline Bec-UF2 & 5' TCGAAGACGATCAGATACCGTG '3 & \multirow{2}{*}{392} & Pitel et al. (2010) \\
\cline { 1 - 2 } Equi-R & 5'TGCCTTAAACTTCCTTGCGAT'3 & & \\
\hline
\end{tabular}

2. DNA amplification reaction (Alhassan et al., 2005): The amplification was performed on a Thermal Cycler (Master cycler, Eppendorf, Hamburg, Germany). The PCR mixture was represented by $50 \mathrm{ml}$ of a mixture $(10 \mathrm{mM}$ Tris- $\mathrm{HCl}$ [pH8.3], $50 \mathrm{~m}$ $\mathrm{MKCl}$, and $1.5 \mathrm{~m} \mathrm{M} \mathrm{MgCl} 2$ ) containing $3 \mathrm{ml}$ of the template DNA, $2.5 \mathrm{pmol}$ of the primers, 0.2 mMdNTP mixture, and $2.5 \mathrm{U}$ of Taq DNA polymerase. The 
mixture was heated for $10 \mathrm{~min}$ at $96^{\circ} \mathrm{C}$ to activate the Taq DNA polymerase and 40 cycles of the following conditions were repeated: denaturation for $1 \mathrm{~min}$. at $96^{\circ} \mathrm{C}$, annealing for $1 \mathrm{~min}$ at $60.5^{\circ} \mathrm{C}$, extension for $1 \mathrm{~min}$ at $72^{\circ} \mathrm{C}$ and a final extension for $10 \mathrm{~min}$ at $72^{\circ} \mathrm{C}$. The amplified products were run in $1.5 \%$ agarose gel electrophoresis (Applichem, Germany, $\mathrm{GmbH}$ ) in 1x TBE buffer stained with ethidium bromide (Bioshop ${ }^{\circledR}$ Canda Inc, Lot No: 0A14667) and captured as well as visualized on UV transilluminator. Two control samples were used for each PCR cycle including T. equi DNA as positive and distilled water as negative control. A 100 bp plus DNA Ladder (Qiagen, Germany, $\mathrm{GmbH}$ ) was used to determine the fragment sizes.

\section{Statistical analysis:}

Chi-square test was used to compare the differences in results between microscopic examination and PCR methods and the infection rates among sex. Results were analyzed using SPSS (Version 17; SPSS Inc., Chicago, USA). A value of $p<0.05$ was considered as statistically significant (Malekifard et al., 2014).

The sensitivity, specificity and accuracy of PCR assay with respect to blood film [gold standard test] (Ibrahim et al., 2011 and Sumbria et al., 2015) were calculated as follows:

Sensitivity of PCR with respect to blood film $=\frac{\text { No. of true positive }}{\text { No. of true positive }+ \text { No. of false negative }} \times 100$
Specificity of PCR with respect to blood film $=\frac{\text { No. of true negative }}{\text { No. of true negative+ No. of false positive }} \times 100$
Accuracy $=\frac{\text { No. of true positive }+ \text { No. of true negative }}{\text { No. of true positive }+ \text { No. of false positive+No. of false negative+No. of true negative }} \times 100$

\section{RESULTS}

Out of 50 blood samples of donkeys examined for T. equi, $14 \%(7 / 50)$ were positive by microscopic examination and 38\% (19/50) by PCR (Table 1 ). All positive samples with microscopic examination were also positive with PCR. There was a high significant difference between the prevalence of $T$. equi by microscopic examination and PCR assay. The prevalence of $T$. equi in male donkeys was $13.6 \%(3 / 22)$ by microscopic examination and $36.4 \%(8 / 22)$ by $P C R$, while in female donkeys was $14.3 \%(4 / 28)$ by microscopic examination and $39.3 \%$ (11/28) by PCR (Table 2 ). No significant difference was recorded between the prevalence rate of infection in males and females. 
Microscopic examination of Giemsa stained blood smears from donkeys revealed forms of theilerial schizogony in lymphocytes (Koch's blue bodies), being irregular shaped structure microschizonts vary from 4-6 $\mu \mathrm{m}$ contain small chromatin granules, $0.41-0.71 \mu \mathrm{m}$ in diameter (mean $0.56 \mu \mathrm{m}$ ) and intra-erythrocytic relatively small, less than $2 \mu \mathrm{m}$ long pear-shaped and ring shaped merozoites of $T$. equi (Figures 1 and 2). The B1 gene specified for T. equi was detected by PCR in 19 blood samples (Figures 3 and 4). The sensitivity, specificity and accuracy of PCR with respect to blood film examination were $61.3 \%, 100 \%$ and $82 \%$, respectively. So, PCR was found to be more sensitive, specificic and accurate than blood film examination.

Table 1. Prevalence of $T$. equi in examined donkeys by using microscopic examination and PCR.

\begin{tabular}{|l|c|c|c|c|c|}
\hline Detection methods & $\begin{array}{c}\text { No. of examined } \\
\text { animals }\end{array}$ & $\begin{array}{c}\text { No. of Positive } \\
\text { samples }\end{array}$ & $\begin{array}{c}\text { Prevalence } \\
(\%)\end{array}$ & $\mathrm{Chi}^{2}$ & $\mathrm{P}$ \\
\hline $\begin{array}{l}\text { Microscopic } \\
\text { examination }\end{array}$ & 50 & 7 & 14 & \multirow{2}{*}{7.484} & $<0.01$ \\
\cline { 1 - 3 } & 50 & $19 * *$ & 38 & & \\
\hline
\end{tabular}

** High significant statistical variation between microscopic examination and PCR.

Table 2. Prevalence of $\mathrm{T}$. equi in examined donkeys according to sex by using microscopic examination and PCR.

\begin{tabular}{|c|c|c|c|c|c|c|c|}
\hline Sex & $\begin{array}{c}\text { No. of } \\
\text { examined } \\
\text { animals }\end{array}$ & $\begin{array}{c}\text { No. of } \\
\text { Positive by } \\
\text { microscopic } \\
\text { examination }\end{array}$ & $\begin{array}{c}\text { Prevalence } \\
\text { (\%) }\end{array}$ & $\begin{array}{l}\text { No. of } \\
\text { Positive } \\
\text { by PCR }\end{array}$ & $\begin{array}{c}\text { Prevalence } \\
\text { (\%) }\end{array}$ & $\mathrm{Chi}^{2}$ & $P$ \\
\hline Male & 22 & 3 & 13.6 & 8 & 36.4 & \multirow{3}{*}{0.585} & \multirow{3}{*}{0.444} \\
\hline Female & 28 & 4 & 14.3 & 11 & 39.3 & & \\
\hline Total & 50 & 7 & 14 & 19 & 38 & & \\
\hline
\end{tabular}

No statistical variation between sexes of animals. 


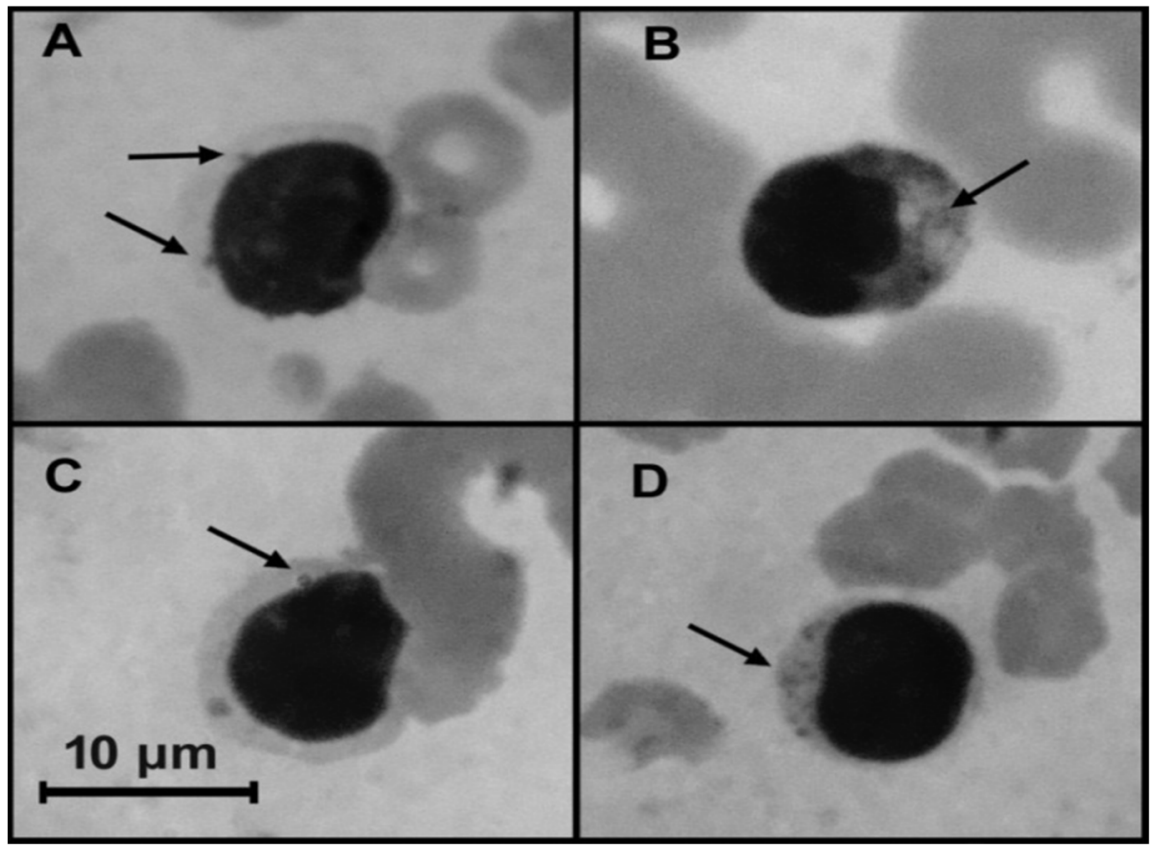

Figure 1. Giemsa stained blood films of donkeys showing forms of theilerial schizogony in lymphocytes. A, B, C, D, showing lymphocytes containing microschizonts of Theileria (Koch's blue bodies) (arrows) (scale bar $10 \mu \mathrm{m}$ ).

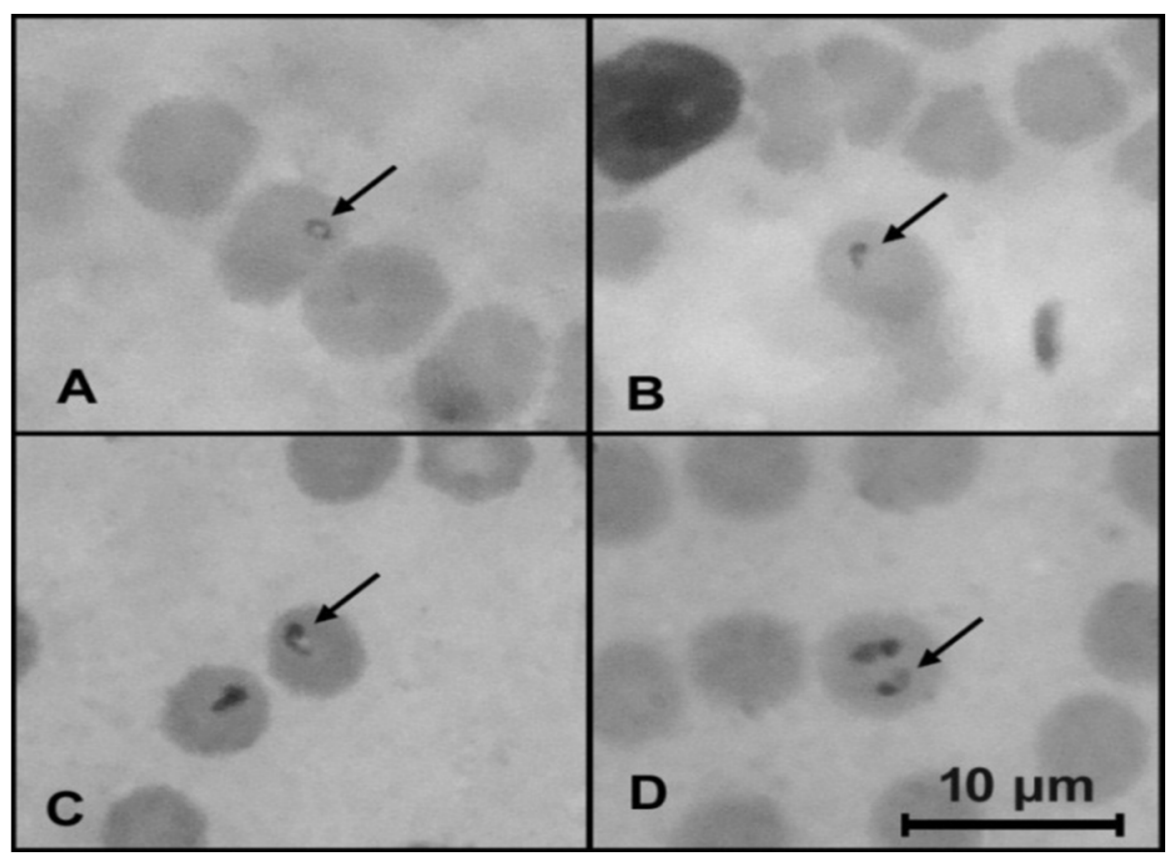

Figure 2. Giemsa stained blood films of donkeys showing intra-erythrocytic pear and ring shaped Theileria equi. A, B, C showing single intra-erythrocytic Theileria while D showing multiple intra-erythrocytic ones (arrows) (scale bar $10 \mu \mathrm{m})$. 


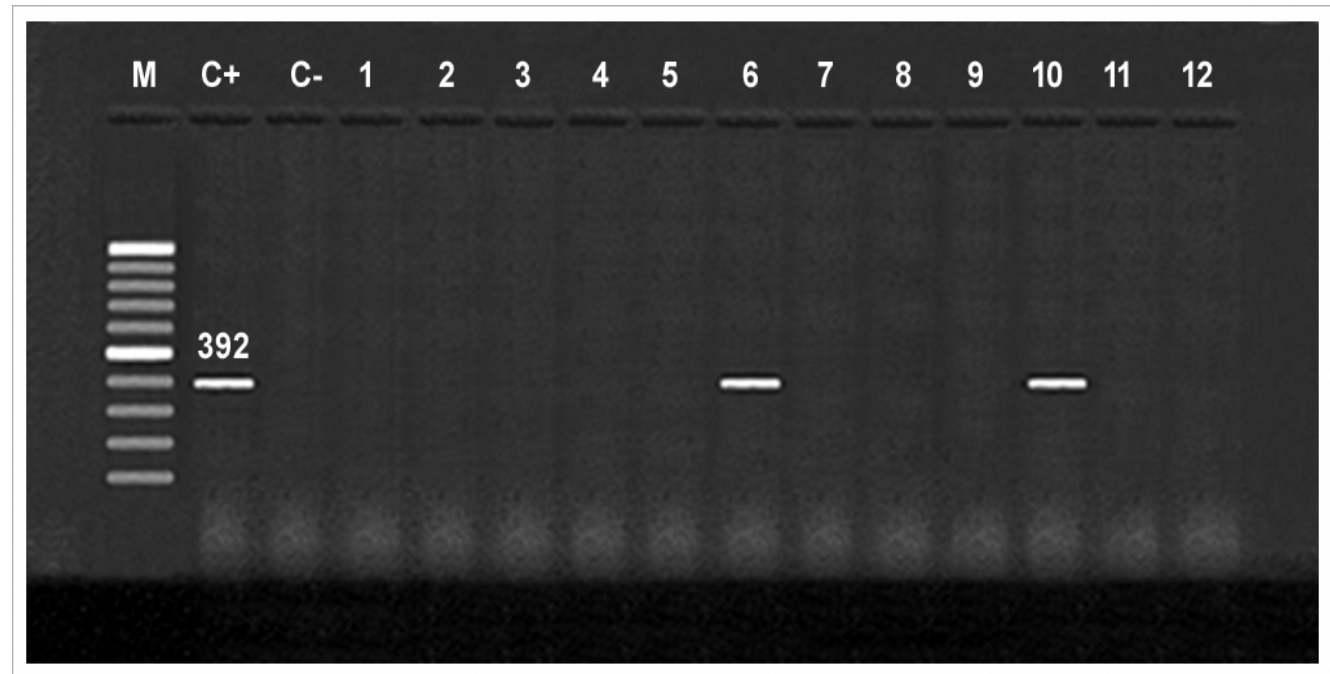

Figure 3. Agarose gel electrophoresis of PCR of Bec-UF2 (392 bp) specific for characterization of Theileria equi. Lane M: 100 bp DNA marker. Lane C+: Positive control for $T$. equi Bec-UF2 gene. Lane C-: Negative control. Lanes 6 and 10: Positive T. equi DNA. Lanes 1, 2, 3, 4, 5, 7, 8, 9, 11 and 12: Negative T. equi DNA.

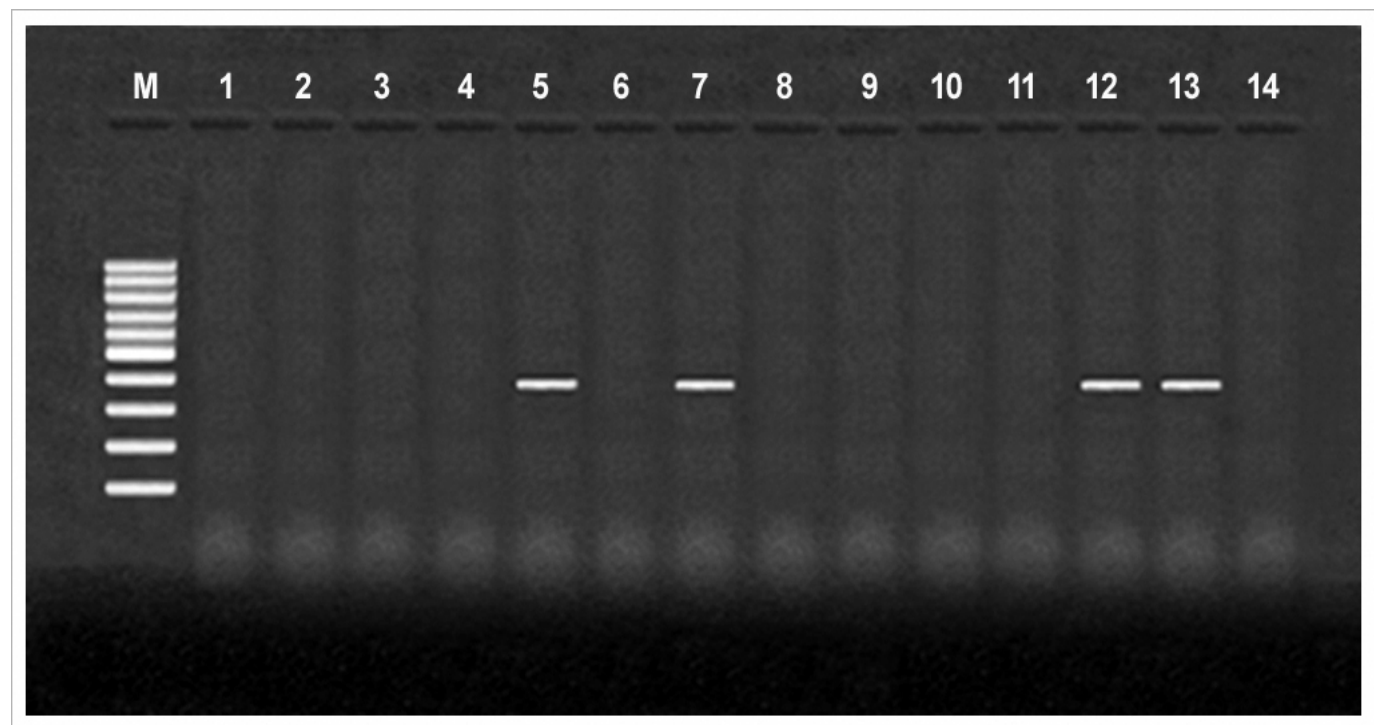

Figure 4. Agarose gel electrophoresis of PCR of Bec-UF2 (392 bp) specific for characterization of Theileria equi. Lane M: 100 bp DNA marker. Lanes 5, 7, 12 and 13: Positive T. equi DNA. Lanes 1, 2, 3, 4, 6, 8, 9, 10, 11 and 14: Negative T. equi DNA. 


\section{DISCUSSION}

Donkeys usually remain asymptomatic carriers of equine theileriosis with positive antibody titre throughout life. The disease is diagnosed by peripheral blood smear examination, but in carrier donkeys it is very difficult to demonstrate the parasite in stained blood smears as the parasitaemia is extremely low (Salib et al., 2013). As donkeys/mules were mainly kept in open yard under poor management condition, hence they are at more risk with respect to vector resulting in haemoparastic infection (Sumbria et al., 2015).

Equine theileriosis, an OIE list disease, caused by tick borne Theileria equi, is responsible for important economic losses in equine industry. The disease can occur in peracute, acute and chronic forms (OIE, 2008). It renders negative effects on the health of equids, decreasing their productivity and work efficacy. T. equi infection can be peracute with death occurring in 1-2 days, or can be chronic, lasting for weeks (Taylor et al., 2007).

Out of 50 donkeys blood samples examined for T. equi, 14\% (7/50) were positive by microscopic examination (ME) and 38\% (19/50) by PCR. Prevalence of $T$. equi had high significant differences between micropscopic examination and PCR assay. Also, Habibi et al. (2016) and Mahdy et al. (2016) found significant differences between ME and PCR on the detection of Theileria equi. The low positive rate for $T$. equi observed in the present study using direct microscopic identification of the parasite in blood smears compared with PCR was in agreement with Ibrahim et al. (2011). Also, the high prevalence of $T$. equi in the present study could be explained by presence of heavy ticks infestation among donkeys in Assiut and donkeys are kept outdoors under poor living condition for daily transport and farm activities, thereby being more exposed to ticks (Sumbria et al., 2015 and 2016). Also, Farah et al. (2003) and Salib et al. (2013) found high prevalence of $T$. equi in Egypt, which is consistent with the current lack of control measures.

In the present study, the prevalence of $T$. equi of donkeys blood samples examined was $14 \%$ by microscopic examination. Our results revealed prevalence of $T$. equi by microscopic examination lower than that reported by Mahdy et al. (2016) as they were $24.8 \%$ and $27.4 \%$ of donkeys and horses, respectively in Giza and Cairo; Salib et al. (2013) 41.61\% of horses in Giza governourate; Ibrahim et al. (2011) 18\% of horses in Egypt. On the other hand, the present results higher than that reported by Habibi et al., (2016) 9.67\% of horses and mules in Iran; Osman et al. (2016) $2.14 \%$ of horse and $2.04 \%$ of donkey in Sudan; Sumbria et al. (2015) $0.93 \%$ in Indiaand Tefera et al. (2011) $2.08 \%$ of donkeys in Ethiopia. These differences in 
infection rates may be related to management practices and due to a difference in the prevalence of tick vector for $T$. equi between different regions, where climatic factors such as temperature, humidity and rainfall influence the habitat for ticks (Oncel et al., 2007).

In the present study, the prevalence of $T$. equi was $38 \%$ of donkey's blood samples examined by polymerase chain reaction (PCR). It is lower than that reported by Habibi et al. (2016) in Iran, $96.77 \%$ of healthy horses and mules; Mahdy et al. (2016) in Giza and Cairo governorates together $50.4 \%$ and $61.9 \%$ of donkeys and horses, respectively; Mahmoud et al. (2016) in Egypt, 36.4\% and $43.1 \%$ of horses and donkeys, respectively and Sgorbini et al. (2015) in Italy, $41 \%$ in horses. The present results are higher than that reported by Davitkov et al. (2016) in central Balkan, $22.5 \%$ of horses; Osman et al. (2016) in Sudan, $13.9 \%$ of horses and $23.6 \%$ of donkeys; Sumbria et al. (2016) in India, $14.14 \%$ of horses, donkey and mules; Laus et al. (2015) in Italy, 17.4\% of donkeys; (Malekifard et al., 2014) in Iran, $10.83 \%$ of horses and (Ibrahim et al., 2011) in Egypt, $26 \%$ of horses. This difference could be attributed to the tick spectrum variation between the study areas and/or differences in persistence of tick vectors transmission and climatic condition between the study areas (Osman et al., 2016).

This study showed a high exposure of donkeys to $T$. equi. None of the donkeys included in the study presented clinical signs of theileriosis at time of blood sampling. Similar findings reported by Machado et al. (2012). Under a high and constant exposure to tick borne pathogens (TBPs), donkeys may acquire high immunity, which makes them chronically infected carriers and takes under-control their clinical symptoms. However, they may still act as a source of TBPs for ticks, enhancing the transmission and facilitating the spread of these agents (Kumar et al., 2009).

In the present study, prevalence of $T$. equi in male donkeys was $13.6 \%$, while in females was $14.3 \%$ by microscopic examination. Also, prevalence of $T$. equi in male donkeys was $36.4 \%$ while in females was $39.3 \%$ by PCR. Therefore, no significant difference between the prevalence rate of infection in males and females were recorded. Similar results were reported by Malekifard et al. (2014) and Salem and ElSherif (2015) who found no significant difference between the prevalence rate of $T$. equi in males and females, which could be due to the condition of enzootic stability of equine theileriosis in the studied area. In contrary, Munkhjargal et al. (2013) and Salib et al. (2013) reported higher infection rate in males than females, While males were significantly less affected than mares (Davitkov et al., 2016 and Sumbria et al., 2016) which most likely is due to different management and housing conditions in these countries. 
In the present study, microscopic examination of Giemsa stained donkey's blood smears revealed forms of theilerial schizogony in lymphocytes (Koch's blue bodies) and intra-erythrocytic relatively small, less than $2 \mu \mathrm{m}$ long pear-shaped and ring shaped merozoites of $T$. equi. This was in agreement with that described by Salib et al. (2013); Malekifard et al.(2014) and Salem and El-Sherif (2015). Also, Soulsby (1982) described $T$. equi as small Babesia being $2 \mu \mathrm{m}$ in length $(<2.5 \mu \mathrm{m})$, pyriform or comparatively rare round or amoeboid with acute angle in pyriform. The morphological characteristics observed in current study were in agreement with the findings of Soulsby, (1982).

The sensitivity, specificity and accuracy of the PCR with respect to blood film examination were $61.3 \%, 100 \%$ and $82 \%$, respectively. PCR was found to be more sensitive, specificic and accurate than blood film examination. Similar results were recorded by Malekifard et al. (2014); Sumbria et al. (2015); Habibi et al. (2016) and Mahdy et al. (2016) who showed PCR was more sensitive than microscopic inspection in diagnosis of $T$. equi infection. Also, Ibrahim et al. (2011) recorded that PCR was found to be highly sensitive and more accurate than blood film examination in diagnosis of $T$. equi infection. The microscopic diagnosis of $T$. equi by thin blood smears lacks enough sensitivity to give an accurate result in cases of low parasitaemia in carrier horses as the parasite has a periodically cryptic nature which obviously leads to false negative results (Bashir et al., 2014 and El-Sayed et al., 2015).

It is concluded that the $T$. equi is prevalent among donkyes in Assiut governourate. Conventional parasitological technique revealed a very low prevalence rate. Molecular techniques, as clearly indicated by this study, have a better in revealing the most real prevalence and endemicity of the disease. Donkeys persistently infected with $T$. equi may act as a source of infection for ticks; therefore, animals should be periodically tested and prophylactically treated. We also recommend the eradication of ticks by the use of acaricides through national program.

\section{REFERENCES}

1. Adaszek Ł., M. Górna, M. Krzysiak, M. Adaszek, M. Garbal and S. Winiarczyk 2011. Identification of the piroplasms isolated from horses with clinical piroplasmosis in Poland. Wiad. Parazytol, 57 (1): 21-26.

2. Alhassan A., W. Pumidonming, M. Okamura, H. Hirata, B. Battsetseg, K. Fujisaki, N. Yokoyama and I. Igarashi 2005. Development of a single-round and multiplex PCR method for the simultaneous detection of Babesia caballi and Babesia equi in horse blood. Veterinary Parasitology, 129 (1-2): 43-49. 
3. Alhassan A., Y. Govind, N.T. Tam, O.M. Thekisoe, N. Yokoyama, N. Inoue and I. Igarashi 2007. Comparative evaluation of the sensitivity of LAMP, PCR and in vitro culture methods for the diagnosis of equine piroplasmosis. Parasitology Research, 100: 1165-1168.

4. Allsopp M.T. ,T. Cavalier-Smith, D.T. De Waal and B.A. Allsopp 1994. Phylogeny and evolution of the piroplasms. Parasitology, 108: 147-152.

5. Allsopp M.T., B.D. Lewis and B.L. Penzhorn 2007. Molecular evidence for transplacental transmission of Theileria equi from carrier mares to their apparently healthy foals. Veterinary Parasitology, 148 (2): 130-136.

6. Bashir S., M.A. Bakheit and E. Sugimoto 2014. Molecular detection of equine trypanosomosis in the Sudan. Vet. Parasitol., 200: 246-250.

7. Böse R., W.K. Jorgensen, R.J. Dalgliesh, K.T. Friedhoff and A.J. De Vos 1995. Current state and future trends in the diagnosis of babesiosis. Veterinary Parasitology, 57(1-3): 61-74.

8. Coles E.H. 1986. Veterinary Clinical Pathology. 4th ed. W.B. Saunders Co. Philadelphia.

9. Davitkov D., M. Vucicevic, J. Stevanovic, V. Krstic, D. Slijepcevic, U. Glavinic and Z. Stanimirovic 2016. Molecular detection and prevalence of Theileria equi and Babesia caballi in horses of central Balkan. Acta Parasitologica, 61(2): 337-342.

10. Davitkov D., M. Vucicevic, J. Stevanovic, V. Krstic, S. Tomanovic, U. Glavinicand Z. Stanimirovic 2015. Clinical babesiosis and molecular identification of Babesia canis and Babesia gibsoni infections in dogs from Serbia. Acta Veterinaria Hungarica, 63:199-208.

11. El-SayedS. A., M. AbdoRizk, M.A. Terkawi, A. Mousa, E.E. El Said, G. Elsayed, M. Fouda, N. Yokoyama and I. Igarashi 2015. Cocktail of Theileria equi antigens for detecting infection in equines. Asian Pac. J. Trop. Biomed., 5(12): 977-981.

12. Farah A.W., N.A. Hegazy, M.M. Romany, Y.A. Solimanand A.M. Daoud 2003. Molecular detection of Babesia equi in infected and carrier horses by polymerase chain reaction. Egypt J. Immunol.,10(2): 73-79.

13. Habibi G., K. Esmaeilnia, M.H. Hablolvarid, A. Afshari, M. Zamen and S. Bozorgi 2016. Microscopic and Molecular Detection of Theileria (Babesia) equi Infection in Equids of Kurdistan Province, Iran. Iran J.Parasitol., 11(1): 86-90.

14. Ibrahim A.K., I.S. Gamil, A.A. Abd-El baky, M.M. Hussein and A.A. Tohamy 2011.Comparative Molecular and Conventional Detection Methods of Babesia equi (B. equI) in Egyptian Equine. Global Veterinaria 7(2): 201-210.

15. Kim C., L. Blanco, A. Alhassan, H. Iseki, N. Yokoyama, X. Xuan and I. Igarashi 2008. Diagnostic real-time PCR assay for the quantitative detection of Theileria equi from equine blood samples. Vet. Parasitol., 151: 158-163. 
16. Knowles D.P., L.S. Kappmeyer and L. E. Perryman 1997. Genetic and biochemical analysis of erythrocyte stage surface antigens belonging to a family of highly conserved proteins of Babesia equi and Theileria species. Mol. Biochem. Parasitol., 90(1): 69-79.

17. Krause P.J. 2003. Babesiosis diagnosis and treatment. Vector Borne Zoonotic Diseases, 3: 45-51.

18. Kumar S., R. Kumar and C. Sugimoto 2009. A perspective on Theileria equi infections in donkeys. Jpn. J. Vet. Res., 56 (4): 171-180.

19. Laus F., A. Spaterna, V. Faillace, F. Veronesi, S. Ravagnan, F. Beribè, M. Cerquetella, M. Meligrana and B. Tesei 2015. Clinical-epidemiological investigation on Theileria equi and Babesia caballi infections in donkeys from central Italy. BMC Vet. Res., 11: 100.

20. Machado R.Z., C.Z. Toledo, M.C. Teixeira, M.R. André, C.R. Freschi and P.H. Sampaio 2012. Molecular and serological detection of Theileria equi and Babesia caballi in donkeys (Equusasinus) in Brazil. Vet. Parasitol. 186(3-4): 461-465.

21. Mahdy O.A., A.M. Nassar, B.S. Mohamed and M.S. Mahmoud 2016. Comparative diagnosis utilizing molecular and serological techniques of Theileria equi infection in distinct equine populations in Egypt. Inter. J. Chem.Tech. Res., 9(6): 185-197.

22. Mahmoud M.S., A. E. El-Hakim, S.H. Hendawy, H.A. Shalaby, O.M. Kandil and N.M. Abu El-Ezz 2015. Diagnosis of Theilria equi infections in equines using Immunoaffinity Purified Antigen. Global Veterinaria, 15(2): 192-201.

23. Mahmoud M. S., N.T. Abu El-Ezz, S. Abdel-Shafy, S.A. Nassar, A.H. El Namaky, W.K. Khalil, D. Knowles, L. Kappmeyer, M.G. Silva and C.E. Suarez 2016. Assessment of Theileria equi and Babesia caballi infections in equine populations in Egypt by molecular, serological and hematological approaches. Parasites and Vectors, 9:260.

24. Malekifard F., M. Tavassoli, M. Yakhchali and R. Darvishzadeh 2014. Detection of Theileria equi and Babesia caballi using microscopic and molecular methods in horses in suburb of Urmia, Iran. Veterinary Research Forum, 5 (2): 129 - 133.

25. Mehlhorn H. and E. Schein 1998. Redescription of Babesia equi Laveran, 1901 as Theileria equi Mehlhorn, Schein 1998. Parasitol. Res., 84(6): 467-475.

26. Munkhjargal T., T. Sivakumar, B. Battsetseg, T. Nyamjargal, M. Aboulaila, B. Purevtseren, D. Bayarsaikhan, B. Byambaa, M.A. Terkawi, N. Yokoyama and I. Igarashi 2013. Prevalence and genetic diversity of equine piroplasms in Tov province, Mongolia. Infect. Genet. Evol., 16: 178-185.

27. OIE 2008. World Organisation for Animal Health, Manual of Diagnostic Tests and Vaccines for Terrestrial Animals. Chapter 2.5.8, equine piroplasmosis, PP: 1-5.

28. OIE 2014. World Organisation for Animal Health, Chapter 2.5.8 equine piroplasmosis; PP: 1-10. 
29. Oncel T., G. Vural, Y. Gicik and M.O. Arslan 2007. Detection of Babesia (Theileria) equi (Laveran, 1901) in Horses in the Kars Province of Turkey. Turkiye Parazitoloji Dergisi, 31(3): 170-172.

30. Osman A.,A. El Ghali and B. Salim 2016. Parasitological and Molecular Detection of Equine Piroplasmosis in Horses and Donkeys in South Darfur State, Sudan. Sudan J. Vet. Res., 31: 21-28.

31. Pitel P., T. Scrive and A. Leon 2010. Molecular detection of Theileria equi and Babesia caballi in the bone marrow of asymptomatic horses Vet. Parasitol., 170:182-184.

32. Rampersad J., E. Cesar, M.D. Campbell, M. Samlal and D. Ammons 2003. A field evaluation of PCR for the routine detection of Babesia equi in horses.Vet. Parasitol., 114: 81-87.

33. Salem N.Y. and M.A. El-Sherif 2015. Malondialdehyde status, trace minerals and hematologic results of anemic - T. equi infected Egyptian horses. Inter. J. Vet. Sci., 4(3): 118-122.

34. Salib F.A., R.R. Youssef, L.G. Rizk and S.F. Said 2013. Epidemiology, diagnosis and therapy of Theileria equi infection in Giza, Egypt. Vet. World 6(2): 76-82.

35. Schein E. 1988. Equine Babesiosis. In: Babesiosis of Domestic Animals and Man. Ristic M. (Ed.); CRC Press, Boca Raton, FL. USA: 197-208.

36. Schein E.,G. Rehbein, W.P. Voigt and E. Zweygarth 1981. Babesia equi (Laveran, 1901). 1. Development in horses and in Iymphocyte culture. Tropenmed. Parasitol., 32(4): 223-237.

37. Sgorbini M., F. Bonelli, S. Nardoni, G. Rocchigiani, M. Corazza and F. Mancianti 2015. Seroprevalence and Molecular Analysis of Babesia caballi and Theileria equi in Horses from Central Italy During a 10-Year Period. Journal of Equine Veterinary Science xx 1-4.

38. Soulsby E.J.L. 1982. Helmints, arthropods and protozoa of domesticated animals. 7th ed. London, UK: Bailliere and Tindall; 719-723.

39. Sumbria D., L.D. Singla, A. Sharma, M.S. Baland S. Kumar 2015. Multiplex PCR for detection of Trypanosoma evansi and Theileria equi in equids of Punjab, India. Veterinary Parasitology; 211(3-4): 293-299.

40. Sumbria D., L.D. Singla and A. Sharma 2016. Theileria equi and Babesia caballi infection of equids in Punjab, India: a serological and molecular survey. Trop. Anim. Health Prod. 48:45-52.

41. Taylor M.A. ,R.L. Coop and R.L. Wall 2007. Veterinary Parasitology. 3rd ed. Oxford: Blackwell Publication, pp. 297.

42. Tefera M., A. Worku, T. Tolosa and M. Bitew 2011. Prevalence and Risk Factors for Donkey Babesiosis in and Around DebreZeit, Central Ethiopia. Veterinary Research, 4(2): 56-60. 


\title{
الكثف الطفيلى والجزيئى لطفيل الثيليريا إكواي فى الحمير بمحافظة أسيوط
}

\author{
هلى محمد محمد قراعه ،باسم رفعت نجيب \\ قسم الطفيليات بععة بحوث صحة الحبوان بأسبوط
}

Email: Huda5380@yahoo.com; Basem79eg@yahoo.com

تعتبر الثيليريا إكواي من طفيليات الدم التى نتتقل عن طريق القراد. البيانات المتعلقة بنسب

الإصابة بالثبليريا إكواى في الحمير نادرة في محافظة أسيوط بمصر للذلك أجرينا هذه الدراسة عن

مدى انتشار عدوى الثيليريا إكواى فى الحمير باستخدام الفحص الميكروسكوبى واختبار تفاعل البلمرة

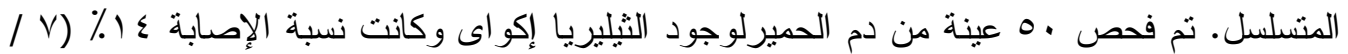

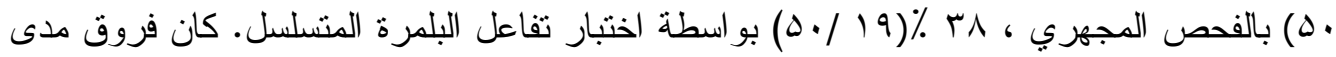
انتتار الثتليريا إكواى ذات دلالة إحصائية عالية بين الفحص المجهري واختبار تفاعل البلمرة

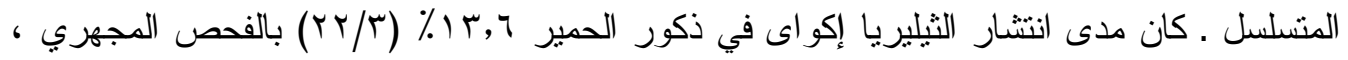

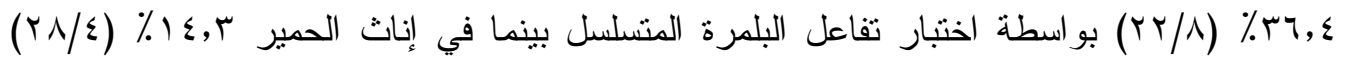

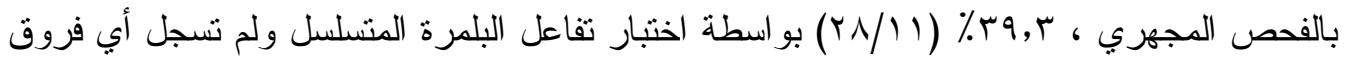
بين معدل انتشار الإصابة في الذكور و الإناث .تبين بالفحص المجهري لمسحات دم الحميروجود

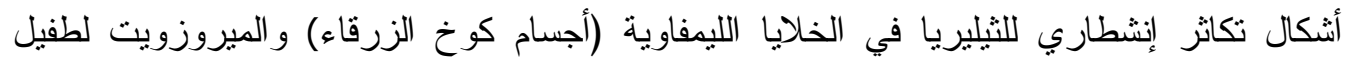

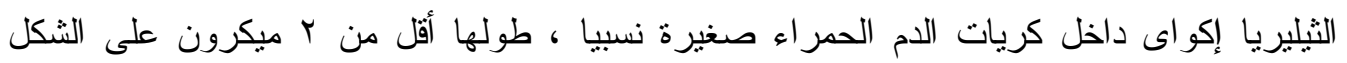
الكمثرى و الدائرى. كما تم الكثف عن الجين B1 المحددة للثيليريا إكواى بواسطة اختبار تفاعل

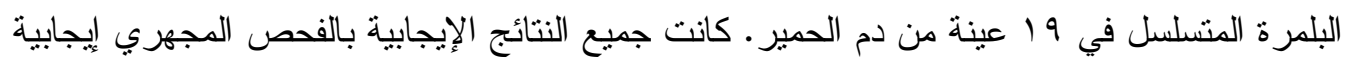
أيضا بواسطة اختبار تفاعل البلمرة المتسلسل. كانت الحساسية والنوعية ودقة اختبار تفاعل البلمرة

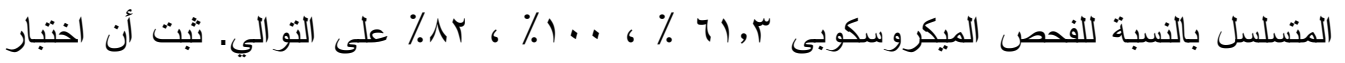
تفاعل البلمرة المتسلسل أكثر حساسية ، نوعية ودقة من الفحص الميكروسكوبى. وبذللك تنشير النتائج إلى أن طفيل الثيليريا إكواى منتشر على نطاق واسع بمحافظة أسيوط بسبب التعرض الكبير للقر اد. 